\title{
Biological, morphological and phytobiogeographic diversity of Malva subovata (DC.) Molero \& J.M. Monts. (Malvales Mal- vaceae) in the Tlemcen region, Algeria
}

\author{
Sarra Ghalem*, Faiçal Hassani, Sid Ahmed Aouadj \& Ibtissam Sarah Bouayed \\ Laboratory of Ecology and Management of Natural Ecosystems, Department of Ecology and Environment, \\ Faculty of Nature and Life Sciences and Earth and Universe Sciences, Abou Bakr Belkaid University, \\ Tlemcen, Algeria \\ *Corresponding author, email: sarah.ghalem@outlook.com
}

\begin{abstract}
The vegetation of the region of western Algeria presents a good example of the study of phyto-diversity. The method of floristic analysis is a main element in the knowledge of natural environments and its rich flora. In my two stations, we carried out floristic surveys, these are a set of observations on the environment and on the vegetation. The study presented is only a part of the objectives of the Laboratory of Plant Ecology focused on the floristic diversity of Malva subovata (DC.) Molero \& J.M.Monts. (Malvales Malvaceae) on the mastery of the biological, morphological and phytobiogeographic capital of the two stations "Boussdra and Hammam Boughrara" in the Tlemcen region. From the treatment of biodiversity indices and the floristic surveys, we were able to conclude that the study area is undergoing a regressive dynamic of vegetation.
\end{abstract}

KEY WORDS Biology; Malva subovata; morphology; phytobiogeographic studies; Tlemcen.

Received 31.08.2020; accepted 30.01.2021; published online 15.02.2021

\section{INTRODUCTION}

Phytogeographic and chorological studies are a very important basis for any conservation and restoration attempt (Quezel, 1999; Aouadj et al., 2020a). They allow us to know the history of a given region and is a true model for interpreting the phenomena of regression (Aouadj et al., 2020b, c).

Aouadj et al. (2020d, e) report that: the floristic sectors and subsectors subdivision is a reflection of the narrow climate-vegetation dependence, based on the phytogeographic division of Barry et al. (1974). Vegetation plays a fundamental role in the structure and functioning of ecosystems, of which it constitutes an expression of the biological potential (Bouayed et al., 2019).

From an ecological point of view, the Mediterranean basin is considered a hotspot because of its very important biological diversity, including endemic plant species. The estimated plant richness is of 25000 species. Mediterranean-type forests account for about twice as many woody species as European-type forests (247 versus 135) (Barbero et al., 1990; Quézel \& Medail, 1995; Medail \& Quézel, 1999). This plant diversity varies from country to country depending on geographical location. The plant richness of the North Africa is estimated between 5000 to 5300 species, represents $15 \%$ of that of the Mediterranean basin (Quézel, 1999). This 
wealth is represented by 3800 species, 900 of which are endemic to Morocco. According to Quézel \& Santa (1962-1963 in Véla \& Benhouhou, 2007), the Algerian flora comprises 3139 species (3744 taxa) including 464 endemic species.

In the assessment established by Medail \& Quézel (1999) and Aouadj et al. (2020f), the Mediterranean forest is made up of approximately 247 woody species compared to European forests (13 species).

Mediterranean plant biodiversity is produced, for many, from a traditional and harmonious use of the environment by humans (Medail \& Quézel, 1999). Despite the incessant attacks they have suffered for a millennium, the Mediterranean forests still offer, in places, appreciable development. There are many methods of studying vegetation. The choice of a technique generally depends on the nature of the vegetation and the object of the study (Kerzabi, 2017). Numerous research programs, through international publications, have underlined the major role of various regions of Tlemcen as an essential reservoir of plant biodiversity (Bouazza et al., 1996).

Mankind, in its nature, has always used its entourage, in particular its natural environment, to meet its needs. It is characterized by its size, density, growth, cultivation, construction, feeding, gathering and predation. All these functions have a negative effect on natural resources. Thus, it is the vital activities of populations that directly influence the components of the environment and generally modify it (Bensenane, 2015; Aouadj et al., 2020g).

In order to better understand the characteristics of plant formations, the study carried out is essentially based on the analysis of exhaustive inventories of the species encountered in the Malva subovata (DC.) Molero \& J.M. Monts (=Lavatera maritima Gouan) (Malvales Malvaceae) (Fig. 1) formations in the 2 study stations, which are characterized by a count of the species, with an identification of their morphological and biological types, and their floristic characters. We will also get to know the study region, which has a very diverse flora and is closely linked to various disturbance factors through biodiversity indices (Ghalem et al., 2020).

\section{MATERIAL AND METHODS}

The analysis of the plant structure takes into ac-

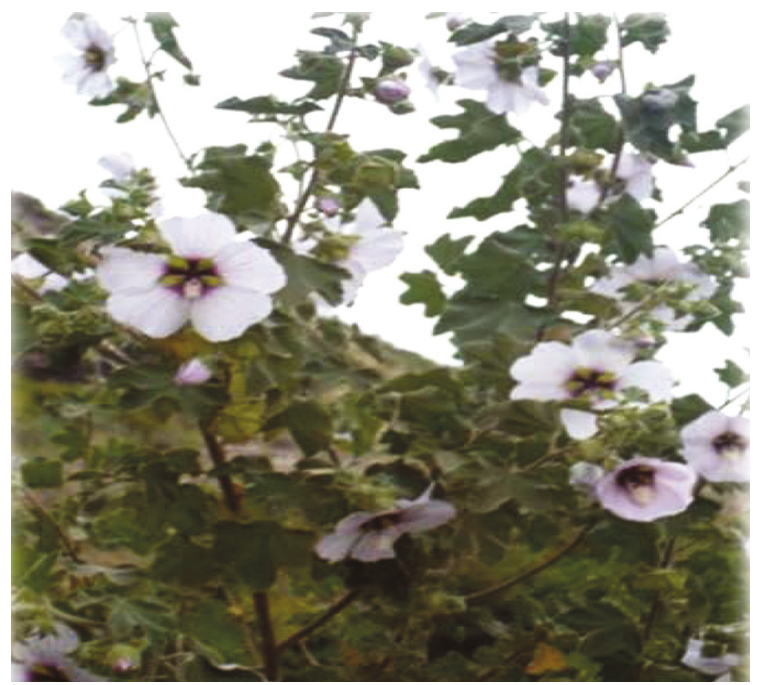

Figure 1. Malva subovata (from Ghalem et al., 2020).
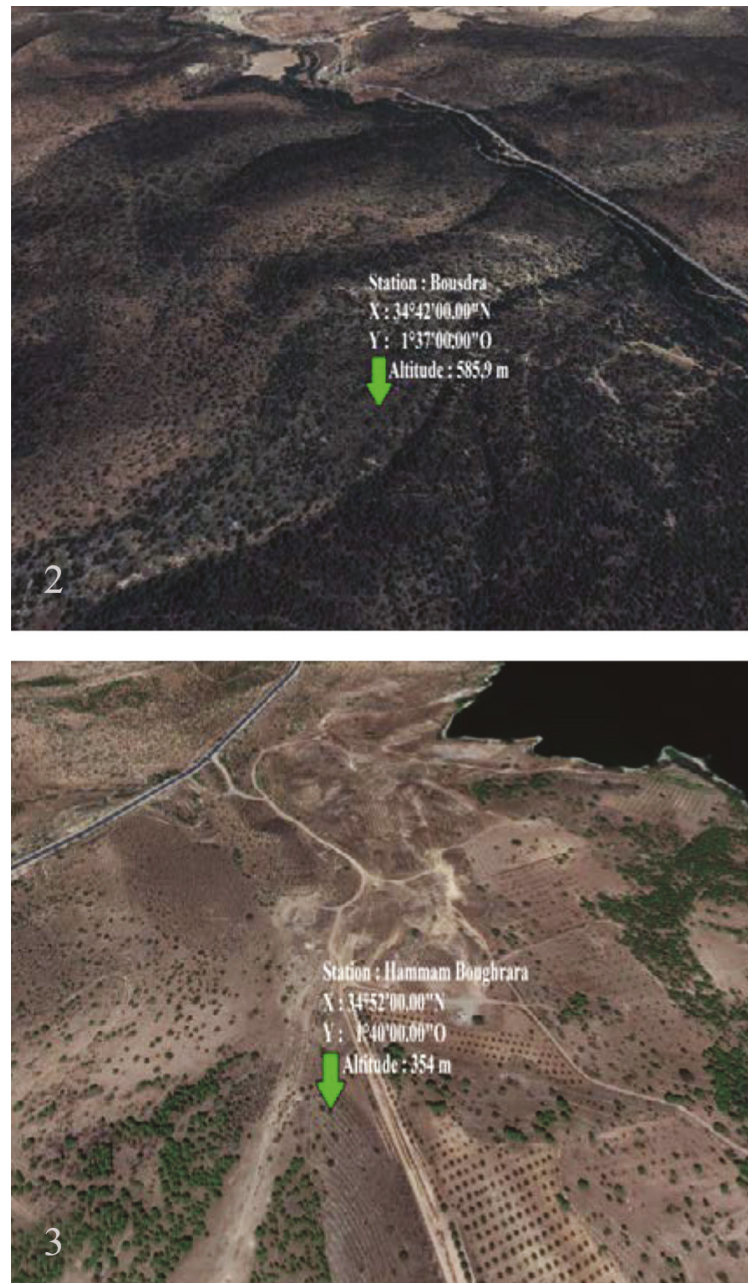

Figures 2, 3. Study areas. 
count the method of floristic surveys, which requires us to list all the plant species present. This floristic list changes from one station to another, from one year to the next in the same station (Raunkiaer, 1934; Bouayad, 2017; Kerzabi, 2017).

Our surveys were carried out during the optimal vegetation period from March to May during the year 2019.

The coordinates of the stations were obtained

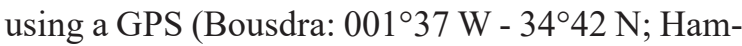
mam Boughrara: $001^{\circ} 40 \mathrm{~W}-34^{\circ} 52 \mathrm{~N}$; Tlemcen, Algeria). Each of these readings includes the general characteristics linked to the station itself (Figs. 2,3). These are: place and date; the altitude; slope; exposure $\mathrm{t}$; plant cover.

Currently, the survey method is based on the Braun-Blanquet method (1952) known as ZurichoMontpellier which consists in determining the smallest surface called "Minimum area" (BraunBlanquet, 1952; Gounot, 1969).

\begin{tabular}{|c|c|c|c|}
\hline Taxa & Family & $\begin{array}{c}\text { Biological } \\
\text { type }\end{array}$ & $\begin{array}{c}\text { Morphol. } \\
\text { type }\end{array}$ \\
\hline Asteriscus maritimus & Asteraceae & $\mathrm{Ch}$ & L.V \\
\hline Asperula hirsuta & Rubiaceae & Th & H.a \\
\hline Avena sterilis & Poaceae & Th & H.a \\
\hline $\begin{array}{l}\text { Anarrhinum frutico- } \\
\text { sum subsp. fruticosum }\end{array}$ & Plantaginaeae & $\mathrm{Ch}$ & L.V \\
\hline Ballota hirsuta & Lamiaceae & $\mathrm{He}$ & H.v \\
\hline $\begin{array}{l}\text { Campanula } \\
\text { dichotoma }\end{array}$ & $\begin{array}{c}\text { Campanula- } \\
\text { ceae }\end{array}$ & Th & H.a \\
\hline $\begin{array}{l}\text { Calycotome } \\
\text { intermedia }\end{array}$ & Fabaceae & $\mathrm{Ch}$ & L.V \\
\hline $\begin{array}{l}\text { Centaurea } \\
\text { involucrata }\end{array}$ & Asteraceae & $\mathrm{He}$ & H.v \\
\hline Centaurea pullata & Asteraceae & $\mathrm{He}$ & H.v \\
\hline Ceratonia siliqua & Fabaceae & $\mathrm{Ph}$ & L.V \\
\hline $\begin{array}{l}\text { Convolvulus } \\
\text { althaoides }\end{array}$ & $\begin{array}{c}\text { Convolvula- } \\
\text { ceae }\end{array}$ & $\mathrm{Th}$ & H.a \\
\hline $\begin{array}{l}\text { Convolvulus } \\
\text { cantabrica }\end{array}$ & $\begin{array}{c}\text { Convolvula- } \\
\text { ceae }\end{array}$ & $\mathrm{He}$ & H.v \\
\hline Cistus villosus & Cistaceae & $\mathrm{Ch}$ & L.V \\
\hline Echium vulgare & Boraginaceae & $\mathrm{He}$ & H.v \\
\hline Eruca vesicaria & Brassicaceae & Th & H.a \\
\hline Fagonia cretica & $\underset{\text { ceae }}{\text { Zygophylla- }}$ & Th & H.a \\
\hline Fumanathymifolia & Cistaceae & $\mathrm{Ch}$ & L.V \\
\hline
\end{tabular}

\section{RESULTS}

\section{The floristic composition (Bousdra station)}

The floristic inventory of the study area allowed us to invent 36 taxa divided into 16 families and 20 genera (Table 1).

\section{The floristic composition (Hammam Boughrara station)}

The floristic inventory of the study area allowed us to invent 68 taxa divided into 26 families and 36 genera (Table 2).

\section{DISCUSSION}

\section{Bousdra station}

Our study area has about 36 species, they belong

\begin{tabular}{|l|c|c|c|}
\hline Galactites duriae & Asteraceae & Th & H.a \\
\hline Genista tricuspidata & Fabaceae & Ch & L.v \\
\hline Inula crithmoides & Asteraceae & Ch & L.v \\
\hline Malva subovata & Malvaceae & Ch & L.v \\
\hline Lavandula dentata & Lamiaceae & Ch & L.v \\
\hline Lavandula stoechas & Lamiaceae & Ch & L.v \\
\hline Lobularia maritima & Brassicaceae & Th & H.a \\
\hline Nepeta multibracteata & Lamiaceae & $\mathrm{He}$ & H.v \\
\hline Olea europea & Oleaceae & $\mathrm{Ph}$ & L.v \\
\hline Quercus coccifera & Fagaceae & $\mathrm{Ph}$ & L.v \\
\hline Sedum sediforme & Crassulaceae & $\mathrm{Ch}$ & H.v \\
\hline Sedum acre & Crassulaceae & $\mathrm{Ch}$ & H.v \\
\hline Stipa parviflora & Poaceae & $\mathrm{Ch}$ & H.v \\
\hline Stachys ocymastrum & Lamiaceae & $\mathrm{Th}$ & H.a \\
\hline Tetraclinis articulata & Cupressaceae & $\mathrm{Ph}$ & L.v \\
\hline Pallenis spinosa & Asteraceae & $\mathrm{He}$ & H.v \\
\hline Phylleria angustifolia & Oleaceae & $\mathrm{Ph}$ & L.v \\
\hline Plantago albicans & Plantagina- & $\mathrm{He}$ & H.v \\
\hline Pistacia lentiscus & Anacardia- & $\mathrm{Ph}$ & L.v \\
\hline
\end{tabular}

Table 1. Floristic composition of Bousdra station. 


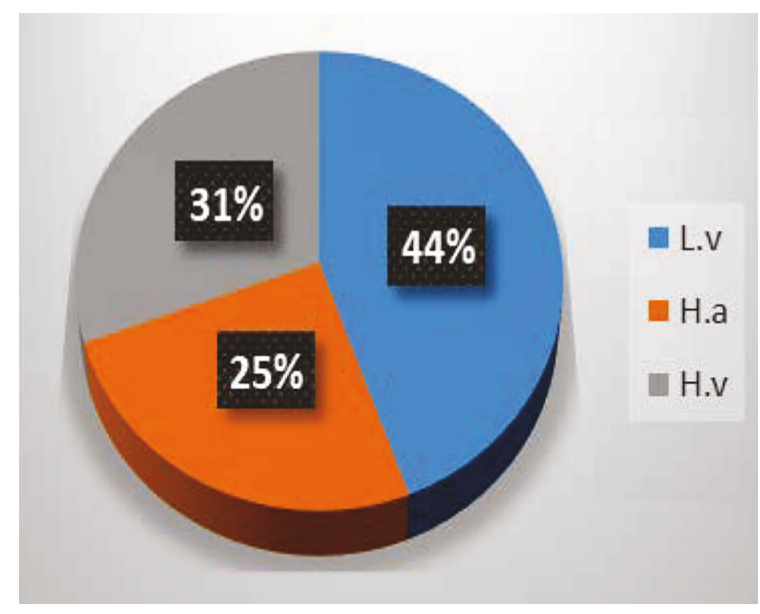

Figure 4. Percentage of morphological types of Bousdra station.

to the subphylum Gymnosperms and Angiosperms with 18 families. The families most represented on a specific level are the Asteraceae with a percentage of $16.66 \%$, the Lamiaceae with the percentage of $13.88 \%$, the Fabaceae remain very little dominant with a percentage of $8.33 \%$ then the Cistaceae, Crassulaceae, Oleaceae, Brassicaceae, Poaceae and Plantaginaceae with the same percentage of 5.55, the other families have the same number with a very low rate (Figs. 4, 5).

On the morphological level, we notice that the perennial woody plants present the highest number in the station Bousdra station with a percentage of $44 \%$, then the perennial grasses with $31 \%$ and finally the annual grasses with the percentage of $25 \%$.

In this station we notice that the Chamaephytes are the best represented with a percentage of $36 \%$, the Therophytes with $25 \%$, the Hemicryptophytes $22 \%$, the Phanerophytes with a low percentage of $17 \%$. We also notice that there is a absence of Geophytes.

-The specific richness of the Bousdra resort: 18 -Total number of species: 36

$$
\begin{aligned}
& \mathrm{D}=\mathrm{S}-1 / \operatorname{lnN} \\
& \mathrm{D}=18-1 / \operatorname{Ln} 36 \quad \mathrm{D}=4.74
\end{aligned}
$$

Simpson indices (Is):

$$
\begin{aligned}
& \mathrm{Is}=1 / \sum \mathrm{Pi}^{2} \\
& \mathrm{Pi}=\mathrm{ni} / \mathrm{N}=0.982 \rightarrow \mathrm{Pi}^{2}=0.0782 \\
& \mathrm{Is}=12.78
\end{aligned}
$$

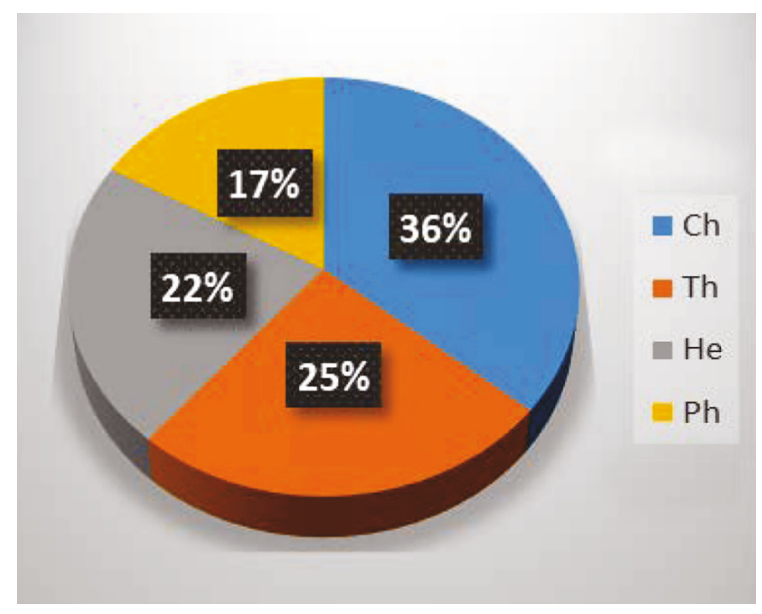

Figure 5. Biological types of the floral procession of Bousdra station. 0.693

Equitability of the simpson index: Es=Is-1/S-1=

Shannon-Weaver indicator: $\mathrm{H}^{\prime}=-\sum \mathrm{pi} \log 2 \mathrm{pi}$

$$
H^{\prime}=-0.982 \log 0.982 \quad H^{\prime}=0.0257
$$

The equity index measures the distribution of individuals within species, regardless of species richness.

$\mathrm{E}=\mathrm{H}^{\prime} / \log \mathrm{S}=0.020 \rightarrow$ Abundance of individuals of each species are equal

\section{Hammam Boughrara station}

Our study area has about 68 species, they belong to the sub-phylum Gymnosperms and Angiosperms with 26 families. The families most represented on a specific level are the Asteraceae with a percentage of $20.58 \%$, and the Poaceae with the percentage of $14.7 \%$, then the Apiaceae $8.82 \%$, the Fabaceae, Brassicaceae, Liliaceae, Cistaceae and Plantaginaceae with the same percentage of $4.47 \%$, the other families have the same number with a very low rate (Figs. 6, 7).

Morphologically, we notice that annual herbs have the highest number in Hammam Boughrara station with a percentage of $47 \%$, then perennial herbs with $44 \%$ and finally perennial woody with a percentage of $9 \%$. In this station we notice that the Therophytes are the best represented with the same percentage of $49 \%$, the Hemicryptophytes 


\begin{tabular}{|c|c|c|c|}
\hline Taxa & Family & $\begin{array}{c}\text { Biological } \\
\text { type }\end{array}$ & $\begin{array}{c}\text { Morphol. } \\
\text { type }\end{array}$ \\
\hline Aegilops triuncialis & Poaceae & Th & H.a \\
\hline Ajuga iva & Lamiaceae & $\mathrm{Th}$ & H.a \\
\hline $\begin{array}{l}\text { Allium porrum subsp. } \\
\text { polyanthum }\end{array}$ & Alliaceae & $\mathrm{He}$ & H.v \\
\hline Allium roseum & Alliaceae & $\mathrm{He}$ & H.v \\
\hline Ammoides verticillata & Apiaceae & $\mathrm{Th}$ & H.a \\
\hline Anacyclus vallentinus & Asteraceae & Th & H.a \\
\hline $\begin{array}{l}\text { Anagalis arvensis } \\
\text { subsp. latifolia }\end{array}$ & Primulaeae & $\mathrm{TH}$ & H.a \\
\hline $\begin{array}{l}\text { Anagalis arvensis } \\
\text { subsp. phonicea }\end{array}$ & Primulaceae & $\mathrm{Th}$ & H.a \\
\hline Anthyllis tetraphylla & Fabaceae & Th & H.a \\
\hline Arisarum vulgare & Araceae & $\mathrm{Ge}$ & H.v \\
\hline $\begin{array}{l}\text { Asphodelus } \\
\text { microcarpus }\end{array}$ & Liliaceae & $\mathrm{Ge}$ & H.v \\
\hline Asteriscus maritimus & Asteraceae & $\mathrm{Ch}$ & L.V \\
\hline Asparagus acutifolius & Liliaceae & $\mathrm{Ge}$ & H.v \\
\hline Atractylis carduus & Asteraeae & $\mathrm{He}$ & H.v \\
\hline Atractylis concellata & Asteraceae & $\mathrm{He}$ & H.v \\
\hline Avena sterilis & Poaceae & Th & H.a \\
\hline Asparagus stipularis & Liliaceae & $\mathrm{Ge}$ & H.v \\
\hline Ballota hirsuta & Lamiaceae & $\mathrm{He}$ & H.v \\
\hline Bellis aпnиа & Asteraceae & Th & H.a \\
\hline $\begin{array}{l}\text { Brachypodium } \\
\text { distachyon }\end{array}$ & Poaceae & Th & H.a \\
\hline Briza minor & Poaceae & Th & H.a \\
\hline Bromus madritensis & Poaceae & Th & H.a \\
\hline Bromus rubens & Poaceae & $\mathrm{Th}$ & H.a \\
\hline Cakile maritima & Brassicaceae & $\mathrm{Th}$ & H.a \\
\hline Calendula arvensis & Asteraceae & Th & H.a \\
\hline Calendula suffruticosa & Asteraceae & Th & H.a \\
\hline $\begin{array}{l}\text { Carduus } \\
\text { pycnocephalus }\end{array}$ & Asteraceae & Th & H.a \\
\hline Carthamus coerulus & Asteraceae & Th & H.a \\
\hline $\begin{array}{l}\text { Convolvulus } \\
\text { althaeoides }\end{array}$ & $\begin{array}{c}\text { Convolvula- } \\
\text { ceae }\end{array}$ & Th & H.v \\
\hline Convolvulus tricolor & $\begin{array}{c}\text { Convolvula- } \\
\text { ceae }\end{array}$ & Th & H.a \\
\hline Cynodon dactylon & Poaceae & $\mathrm{Ge}$ & H.v \\
\hline Cytisus villosus & Fabaceae & $\mathrm{Ch}$ & L.v \\
\hline DactyIis glomerata & Poaceae & $\mathrm{Ge}$ & H.v \\
\hline $\begin{array}{l}\text { Daucus carota subsp. } \\
\text { maximus }\end{array}$ & Apiaceae & $\mathrm{He}$ & H.v \\
\hline
\end{tabular}

\begin{tabular}{|c|c|c|c|}
\hline Echinophora spinosa & Apiaceae & $\mathrm{Ch}$ & H.v \\
\hline Echinops spinosus & Asteraceae & $\mathrm{He}$ & H.v \\
\hline Echium vulgare & Boraginaceae & $\mathrm{He}$ & H.v \\
\hline Fagonia cretica & $\begin{array}{c}\text { Zygophylla- } \\
\text { ceae }\end{array}$ & $\mathrm{He}$ & H.v \\
\hline Ferula communis & Apiaceae & $\mathrm{He}$ & H.v \\
\hline Ferula lutea & Apiaceae & $\mathrm{He}$ & H.v \\
\hline Fumana thymifolia & Cistaceae & $\mathrm{Ch}$ & L.V \\
\hline Galactites duriae & Asteraceae & Th & H.A \\
\hline $\begin{array}{l}\text { Helianthemum } \\
\text { apertum }\end{array}$ & Cistaceae & Th & H.a \\
\hline Helianthemum hirtum & Cistaceae & Th & H.a \\
\hline Hordeum murinum & Poaceae & Th & H.a \\
\hline Lagurus ovatus & Poaceae & Th & H.a \\
\hline Lavandula multifida & Lamiaceae & $\mathrm{Ch}$ & H.v \\
\hline Malva subovata & Malvaceae & $\mathrm{Ch}$ & L.V \\
\hline $\begin{array}{l}\text { Limonium sinuatum } \\
\text { subsp. eusinuatum }\end{array}$ & $\begin{array}{c}\text { Plumbagina- } \\
\text { ceae }\end{array}$ & $\mathrm{He}$ & H.v \\
\hline Lobularia maritima & Brassicaceae & Th & H.a \\
\hline Olea europaea & Oleaceae & $\mathrm{Ph}$ & L.V \\
\hline Phagnalon saxatile & Asteraceae & $\mathrm{Ch}$ & H.v \\
\hline Pallenis spinosa & Asteraceae & $\mathrm{He}$ & H.v \\
\hline Papaver rhoeas & Paveraceae & Th & H.a \\
\hline Paronychia argentea & $\begin{array}{c}\text { Caryophylla- } \\
\text { ceae }\end{array}$ & $\mathrm{He}$ & H.v \\
\hline Plantago albicans & $\begin{array}{l}\text { Plantagina- } \\
\text { ceae }\end{array}$ & $\mathrm{He}$ & H.v \\
\hline Plantago lagopus & $\begin{array}{l}\text { Plantagina- } \\
\text { ceae }\end{array}$ & $\mathrm{He}$ & H.v \\
\hline Plantago psyllium & $\begin{array}{l}\text { Plantagina- } \\
\text { ceae }\end{array}$ & $\mathrm{Th}$ & H.a \\
\hline Pistacia lentiscus & $\begin{array}{l}\text { Anacardia- } \\
\text { ceae }\end{array}$ & $\mathrm{Ph}$ & L.V \\
\hline Thapsia garganica & Apiaceae & $\mathrm{He}$ & H.v \\
\hline Reseda alba & Resedaceae & $\mathrm{Th}$ & H.a \\
\hline $\begin{array}{l}\text { Rumex } \\
\text { bucephalophorus }\end{array}$ & Polygonaceae & $\mathrm{Th}$ & H.a \\
\hline Ruta chalepensis & Rutaceae & $\mathrm{Ch}$ & H.v \\
\hline Sedum sediforme & Crassulaceae & $\mathrm{He}$ & H.v \\
\hline Sonchus asper & Asteraceae & $\mathrm{Th}$ & H.a \\
\hline Sinapis alba & Brassicaceae & Th & H.a \\
\hline Ononis pubescens & Fabaceae & $\mathrm{Th}$ & H.a \\
\hline $\begin{array}{l}\text { Opuntia maxima }= \\
\text { O. ficus-indica }\end{array}$ & Cactaceae & $\mathrm{Ch}$ & H.v \\
\hline
\end{tabular}

Table 2. Floristic composition of Hammam Boughrara station. 




Figure 6. Percentage of morphological types of the Hammam Boughrara station.

with $26 \%$, the Chamaephytes with a percentage of $13 \%$, the Geophytes $9 \%$ and finally we notice that there is a very low percentage of Phanerophytes of $3 \%$.

Total number of species: 68

$\mathrm{D}=\mathrm{S}-1 / \mathrm{lnN} \longrightarrow \mathrm{D}=26-1 / \operatorname{Ln} 68 \longrightarrow \mathrm{D}=5.92$

Simpson indices (Is):

$\mathrm{Is}=1 / \sum \mathrm{Pi}^{2} \longrightarrow \mathrm{Pi}=\mathrm{ni} / \mathrm{N}=0.987 \longrightarrow \mathrm{Pi}^{2}=$ $0.0872 \longrightarrow \mathrm{Is}=11.46$

Equitability of the Simpson index:

$\mathrm{Es}=\mathrm{Is}-1 / \mathrm{S}-1=0.418$

Shannon-Weaver indicator: $\mathrm{H}^{\prime}=-\sum$ pi $\log 2 \mathrm{pi}$ $\mathrm{H}^{\prime}=-0.987 \log 0.987 \longrightarrow \mathrm{H}^{\prime}=0.0186$

So only one species is present.

The equity index measures the distribution of individuals within species, regardless of species richness.

$\mathrm{E}=\mathrm{H}^{\prime} / \log \mathrm{S}=0.013 \longrightarrow$ Abundance of individu als of each species are equal

\section{CONCLUSIONS}

The exhaustive inventory carried out at the two study stations (Bousdra, Hammam Boughrara) enabled us to study the following characterizations:

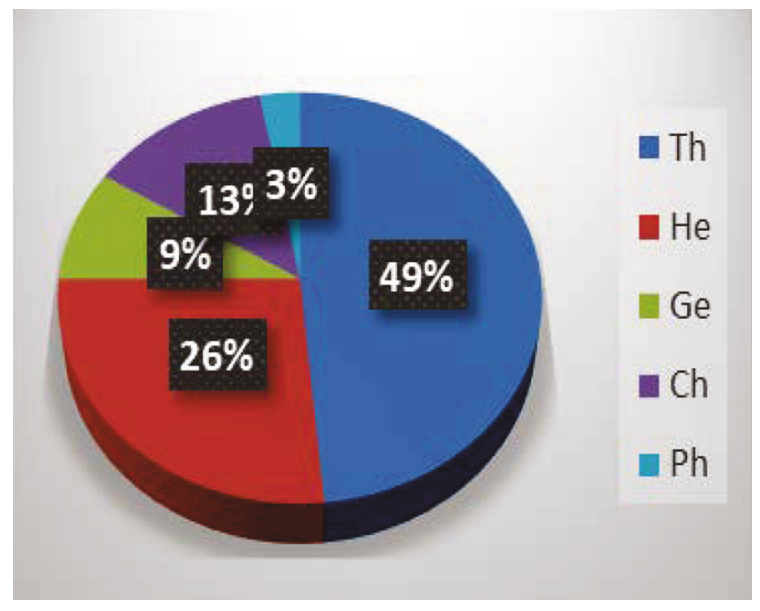

Figure 7. Biological types of the floral procession of the Hammam Boughrara station.

biological and morphological, followed by the distribution of families.

This study allowed us to bring out the following results:

dominance of perennial woody plants in the Boussdra resort and the dominance of annual herbaceous plants in the Hammam Boughrara resort from a morphological point of view;

importance of therophytes which confirms the phenomenon of therophytization in the Hammam boughrara station;

type vegetation: $\mathrm{TH}>\mathrm{He}>\mathrm{Ch}>\mathrm{Ge}>\mathrm{PH}$ for the Hamma boughrara station;

special attention is generally paid to the distribution of Therophytes, the proportion of which in the Mediterranean region is around $50 \%$;

the rate of theophytes is linked, whatever the scale of the analysis and the level of perception adopted, to the openness of the vegetation and the overall humidity of the environment;

type vegetation: $\mathrm{Ch}>\mathrm{Th}>\mathrm{He}>\mathrm{Ph}$ for the Bousdra station;

grazing favors the overall establishment of the Chamaephytes often refused by the herd;

we consider the Chamaephytes to be better adapted to low temperatures and aridity;

the most dominant families in the field for the two stations are: Asteraceae, Poaceae and Lamiaceae;

the biological types constitute indices of the life strategy of species. 


\section{REFERENCES}

Aouadj S.A., Nasrallah Y. \& Hasnoui O., 2020a. Regional phytogeographic analysis of the flora of the Mounts of Saida (western Algeria): evaluationrestoration report. Biodiversity Journal, 11: 25-34. https://doi.org/10.31396/Biodiv.Jour.2020.11.1.25. 34

Aouadj S.A., Hasnoui O. \& Nasrallah Y., 2020b. Approche ethnobotanique et inventaire floristique des plantes médicinales dans la région de Doui Thabet (SaidaOuest Algérien). Phyto Chem \& Bio Sub Journal, 14: 92-104. https://doi.org/10.163.pcbsj/2020.14.-1-92

Aouadj S.A., Nasrallah Y. \& Hasnoui O., 2020c. Ecological characterization and evaluation of the floristic potential of the forest of Doui Thabet (Saida Western Algeria) in the context of the restoration. Ecology, Environment and Conservation, 26: 266-278.

Aouadj S.A., Nasrallah Y. \& Hasnoui O., 2020d. Note on the orchids of mounts of Saida (Saida Western Algeria) in the context of the restoration. Ecology, Environment and Conservation, 26: 37-45.

Aouadj S.A., Nasrallah Y., Hasnoui O. \& Khatir H., 2020e. Impacts of anthropogenic pressure on the degradation of the forest of Doui Thabet (Saida, Western Algeria) in the context of the restoration. Acta scientifica naturalis, 7: 88-97. https://doi.org/ 10.2478/asn-2020-0022

Aouadj S.A., Nasrallah Y., Hasnoui O. \& Khatir H., 2020f. Impact of ecological restoration techniques on the dynamics of degraded ecosystems of the mounts of Saida: Case of the forests of Doui Thabet (West Algeria). Acta scientifica naturalis, 7: 98-121. https:// doi.org/10.2478/asn-2020-0023

Aouadj S.A., Nasrallah Y., Hasnoui O. \& Khatir H., 2020g. Rare, endemic and threatned flora of the mounts of Saida (western Algeria). Agrobiologia, 11: 45-57.

Barbero M., Quézel P. \& Loisel R., 1990. Les apports dela phytoécologie dans l'interprétation deschangements et perturbations induits par l'hommesur les écosystèmes forestiers méditerranéens. Forêt Méditerranéenne, 12: 194-215.

Barry J.P., Celles J.C. \& Faurel L., 1974. Carte international du tapis végétal. Ech : 1/1000000. Alger. 1 carte.

Bensenane I., 2015. Assessment of anthropogenic actions of the last three decades in the steppe region of ElGor and Sidi-Djilali (West Algeria); eco-floristic aspects. Thése Doct. Université de Tlemcen, 120 pp.

Bouazza M., Benabadji N., Metge G. \& Loisel R., 1996. Description et aspect des sols en région semi- aride et aride au Sud de Sebdou (Orranie- Algérie). Bulletin Institut Sciences de Rabat, 20: 77-86.

Braun-Blanquet J., 1952. Les groupements vegetaux del France meditérranéenne. Editions C.N.R.S., Montpellier, $297 \mathrm{pp}$.

Bouayed I.S., Hassani F. \&. Ghalem S., 2019. Etude morphométrique d'une espèce menacée (fortement anthropisée): Withania frutescens "solanacées" dans l'Algérie Occidentale. Algerian Journal of Environmental Science and Technology, 5: 1121-1126.

Ghalem S., Hassani F., Bensouna A, Khatir H. \& Aouadj S.A., 2020. Floristic cortege of the genre Lavatera a Malvaceae forthe two species: Lavatera maritima and L. flava in the region of Sabra (Tlemcen, Western of Algeria). Ecology, environment and Conservation, 26: S392-S397.

Gounot M., 1969. Methods of quantitative study of vegetation. 1 Vol. Ed. March. Paris, pp. 314-341.

Médail P. \& Quézel P., 1999. Biodiversity hotspots in the Mediterranean basin: setting global conservation priorities. Conservation Biology, 13: 1510-1513.

Quézel P., 1999. Large vegetation structures in the Mediterranean region: determining factors in their post-glacial development. Geobios, 32: 19-32.

Quézel P. \& Médail, 1995. La région circum-méditerranéenne: centre mondial majeur de biodiversité végétale. In: Actes des 6e Rencontres del'ARPE Provence-Alpes-Côte d'Azur, Colloque scientique international "Bio'Mes", Gap, pp. 152-160.

Kerzabi R., 2017. The anthropogenic effect on halophyte vegetation in the semi-arid and arid environment of Orania; Vegetation dynamics in relation to edaphic factors, $123 \mathrm{pp}$.

Raunkiaer C., 1934. The life forms of plants and statistical plant geography. Ed. Clarendon Press, Oxford, $632 \mathrm{pp}$.

Véla E. \& Benhouhou S., 2007. Evaluation d'un nouveau point chaud de biodiversité végétale dans le Bassin méditerranéen (Afrique du Nord). C.R. Biologies, 330: 589-605. https://doi.org/10.1016/j.crvi.2007. 04.006 
. 